\title{
Differentiation of $\mathrm{CD}^{\circ}{ }^{-} / \mathrm{CD}^{+} 1^{+}$lung side population cells into endothelial and smooth muscle cells in vitro
}

\author{
YANG XU $^{1^{*}}$, PING SUN $^{2 *}$, JIAN-YU WANG $^{1 *}$, ZONG-ZE LI $^{1}$, RUI-LAN GAO ${ }^{3}$, XUE-ZHE WANG $^{4}$, \\ WILLIAM D. PHILLIPS ${ }^{5}$ and SIMON X. LIANG $^{1}$
}

${ }^{1}$ Department of Biochemistry and Molecular Biology, College of Basic Medical Sciences, Jinzhou Medical University, Jinzhou, Liaoning 121000; ${ }^{2}$ Department of Hematology, Jining First People's Hospital, Jining, Shandong 272000; ${ }^{3}$ Institution of Hematology Research, The First Affiliated Hospital of Zhejian Chinese Medical University, Hangzhou, Zhejiang 310006; ${ }^{4}$ Department of Clinical Laboratory, The First Affiliated Hospital of Jinzhou Medical University, Jinzhou, Liaoning 121001, P.R. China; ${ }^{5}$ School of Medical Sciences (Physiology) and Bosch Institute, University of Sydney, Sydney, NSW 2006, Australia

Received July 4, 2018; Accepted December 27, 2018

DOI: $10.3892 /$ ijmm.2019.4053

\begin{abstract}
Side population (SP) cells are a small subpopulation of cells found in many mammalian tissues and organs, identified by their capacity to efflux Hoechst 33342 dye. They are enriched for stem/progenitor cell activity. SP cells isolated from the adult mouse lung can be separated into a CD45 subset (bone marrow-derived) and a CD45 subset that can be subdivided into $\mathrm{CD} 31^{-}$and $\mathrm{CD} 31^{+}$subpopulations. $\mathrm{CD} 45^{-} / \mathrm{CD} 31^{-}$ lung SP (LSP) cells are known to be mesenchymal stem cells. However, CD $45 / \mathrm{CD} 31^{+}$LSP cells are not fully characterized. In the present study, it was found that CD $45 / \mathrm{CD} 31^{+} \mathrm{LSP}$ cells were able to form colonies. Based on the expression of vascular endothelial growth factor receptor 2 (VEGFR2), these cells were separated into VEGFR2- and VEGFR2 ${ }^{+}$cells. The CD $45 \%$ CD $31^{+} /$VEGFR2- LSP cells expressed genes characteristic of smooth muscle and endothelial progenitors, and were
\end{abstract}

Correspondence to: Dr Simon X. Liang, Department of Biochemistry and Molecular Biology, College of Basic Medical Sciences, Jinzhou Medical University, 40, Songpo Road, Jinzhou, Liaoning 121000, P.R. China

E-mail: simon1308@163.com

*Contributed equally

Abbreviations: SP, side population; LSP, lung side population; MP, main population; LMP, lung main population; VEGFR2, vascular endothelial growth factor receptor 2; CSP, cardiac side population; FACS, fluorescence-activated cell sorting; DMEM, Dulbecco's modified Eagle's medium; Dil-Ac-LDL, Dil-labeled acetylated low-density lipoprotein; DAPI, 4-6-diamidino-2phenylindol-dihydrochloride; vWF, von Willebrand factor; $\alpha$ SMT, $\alpha$-smooth muscle tropomyosin; $\alpha \mathrm{SMA}, \alpha$-smooth muscle actin

Key words: side population cells, lung, endothelial cells, smooth muscle cells, stem cells able to differentiate into smooth muscle and endothelial cells in vitro. The $\mathrm{CD} 45 / \mathrm{CD} 31^{+} / \mathrm{VEGFR} 2^{+} \mathrm{LSP}$ cells expressed genes characteristic of endothelial progenitors and gave rise to endothelial cells, although not smooth muscle, in vitro. The data demonstrate that CD45/CD31 ${ }^{+} / \mathrm{VEGFR} 2-$ LSP cells differentiated into $\mathrm{CD} 45 / \mathrm{CD} 31^{+} / \mathrm{VEGFR} 2^{+} \mathrm{LSP}$ cells and then endothelial cells, indicating that CD $45 / \mathrm{CD} 31^{+} / \mathrm{VEGFR} 2^{+} \mathrm{LSP}$ cells are likely to be derived from CD45/CD $31^{+} /$VEGFR2 $-\mathrm{LSP}$ cells. Taken together, the results suggest that $\mathrm{CD} 45^{\circ} / \mathrm{CD} 31^{+} \mathrm{LSP}$ cells can be separated into CD45/CD31+/VEGFR2- LSP cells, which may be progenitors of endothelial and smooth muscle, whereas $\mathrm{CD} 45 \% \mathrm{CD} 31^{+} / \mathrm{VEGFR} 2^{+}$LSP cells may serve as late commitment endothelial progenitors in the adult mouse lung.

\section{Introduction}

Chronic pulmonary diseases, including pulmonary hypertension, chronic obstructive pulmonary disease and interstitial pulmonary fibrosis, constitute major contributors to morbidity and mortality rates $(1,2)$. The use of stem cells for cell-based therapy in chronic pulmonary diseases has been under investigation (3-8). In previous years, different populations of lung stem- or progenitor-cells have been reported to reside within the adult mouse lung. They are thought to be involved in tissue maintenance and repair, however, they may also contribute to pulmonary diseases $(4,5,8)$. Using different markers and methods, these cells have been variously described as: i) Airway clara cells (9), ii) alveolar type II cells (10), iii) lung c-kit positive cells $(11,12)$, and iv) lung side population (LSP) cells (13-16). SP cells are identified by their capacity to efflux Hoechst 33342 dye, allowing the weakly-labeled SP cells to be distinguished from the intensely-labeled main population (MP) of cells (17-19). This unique property is mediated through the action of the p-glycoprotein multidrug/ATP-binding cassette transporter protein, ATP-binding cassette super-family G member 2 (ABCG2) on the surface of SP cells, which pumps Hoechst dye out of the cell $(20,21)$. SP cells have been found in numerous adult mammalian tissues and organs, including 
bone marrow, the heart, liver, skeletal muscle, brain, kidney and lung (14,19,21-23). These cells are rare and they are enriched for stem/progenitor cell activity.

Several studies have suggested that LSP cells are capable of differentiation into epithelial cells, endothelial cells, smooth muscle cells and mature hematopoietic cells $(13-16,24)$. LSP cells are known to be heterogeneous $(13,14,24,25)$. Based on their expression of CD45, LSP cells can be separated into CD $45^{+}$and $\mathrm{CD}^{4} 5^{-}$subpopulations. CD $45^{+} \mathrm{LSP}$ cells possess hematopoietic progenitor and stem cell activity, and are most likely bone marrow-derived (14,24). By contrast, CD45- LSP cells can be further divided into CD $45^{-} / \mathrm{CD} 31^{-}$and CD $45^{\circ} / \mathrm{CD} 31^{+}$ subpopulations $(15,24)$. The $\mathrm{CD} 45^{\circ} / \mathrm{CD} 31^{-}$subpopulation has been shown to comprise resident mesenchymal progenitor cells, capable of differentiating in vitro into cartilage, bone and adipose cells (15). However, the nature and differentiation potential of $\mathrm{CD} 45^{-} / \mathrm{CD} 31^{+} \mathrm{LSP}$ cells remain to be fully elucidated. Our previous study demonstrated that CD45- LSP cells may be progenitors of endothelial and smooth muscle cells in the embryonic mouse lung $(14,24)$. In addition, it has been suggested that mouse heart and lung tissues, including blood vessel cells, may share a novel population of progenitor cells (26). In the adult mouse heart, the stem cell antigen-1 $(\mathrm{SCA} 1)^{+} / \mathrm{CD} 31^{+}$subpopulation of cardiac SP (CSP) cells have been reported to be endothelial progenitors $(27,28)$. Therefore, it was hypothesized that $\mathrm{CD} 45^{-} / \mathrm{CD} 31^{+} \mathrm{LSP}$ cells may serve as progenitors of endothelial and smooth muscle cells in the adult mouse lung. Previous studies have indicated that CD45/VEGFR2 ${ }^{+}$LSP cells may be endothelial progenitor cells in the adult mouse lung. The association between $\mathrm{CD} 45^{-} / \mathrm{CD} 31^{+}$ and CD45/VEGFR2 ${ }^{+}$LSP cells remains to be elucidated. The present study aimed to characterize CD $45 \% \mathrm{CD} 31^{+} \mathrm{LSP}$ cells in the adult mouse lung, to clarify their differentiation potential, and to examine the association between these two types of LSP cells in vitro.

\section{Materials and methods}

Animals. Female wild-type C57BL/6J mice (aged 8-10 weeks, weighting 22-25 g) were purchased from Beijing HFK-Biotechnology (Beijing, China). The mice were group-housed in individually-ventilated cages under pathogen-free conditions. The mice were maintained under a $12 \mathrm{~h} \mathrm{light/dark}$ photoperiod, at $20 \pm 1^{\circ} \mathrm{C}$ with $60 \pm 10 \%$ relative humidity and food and water were provided ad libitum. The general health status of the animals was monitored daily. Animal care, handling and all animal experiments described herein were conducted strictly according to ethical standards approved by the Animal Ethical Committee of Jinzhou Medical University (Jinzhou, China; approval ID: LY2014D001).

CD45 /CD31 ${ }^{+}$LSP cell isolation, fluorescence-activated cell sorting (FACS) and analysis. The LSP cells were isolated as previously described $(14,15,28,29)$. Briefly, the mice were sacrificed by isoflurane anesthesia followed by cervical dislocation. Prior to lung extraction, animals were bled by transecting the abdominal aorta. Subsequently, in an attempt to remove circulating blood cells, perfusion of the pulmonary vasculature was performed using ice-cold saline until the lungs were bleached white. The lung extracts were then digested by finely mincing tissue with a razor blade in the presence of $0.1 \%$ collagenase (Roche Diagnostics, Indianapolis, IN, USA), $2.4 \mathrm{U} / \mathrm{ml}$ dispase (Roche Diagnostics), and $2.5 \mathrm{mM} \mathrm{CaCl}_{2}$ at $37^{\circ} \mathrm{C}$ for $1 \mathrm{~h}$. Removal of nonspecific debris was accomplished by sequential filtration through 70 - and $40-\mu \mathrm{m}$ filters, and the cells were resuspended at a density of $1 \times 10^{6}$ cells $/ \mathrm{ml}$. Cell staining was performed by incubating with Hoechst 33342 (5 $\mu \mathrm{g} / \mathrm{ml}$; Sigma-Aldrich; Merck KGaA, Darmstadt, Germany) at $37^{\circ} \mathrm{C}$ for $90 \mathrm{~min}$ in the presence or absence of verapamil (50 mM; Sigma-Aldrich; Merck KGaA) (21). The suspension was subsequently incubated with one or more fluorescently-conjugated monoclonal rat anti-mouse antibodies, including anti-CD45-PerCP-Cy5.5 (1:100; cat. no. 550994; BD Biosciences, Franklin Lakes, NJ, USA), anti-CD31-PE (1:100; cat. no. 553373; BD Biosciences), anti-VEGFR2-APC (1:100; cat. no. 561993; BD Biosciences), anti-SCA1-FITC (1:100; cat. no. 557405; BD Biosciences) and anti-c-kit-FITC (1:100; cat. no. 561680; BD Biosciences). Isotype control antibodies were used in parallel as negative controls and to establish gating parameters for positively stained cells. All incubations were performed for $30 \mathrm{~min}$ at $4^{\circ} \mathrm{C}$ in the dark.

FACS was conducted using the MoFlo ${ }^{\mathrm{TM}}$ XDP flow cytometer (Beckman Coulter, Inc., Brea, CA, USA) to isolate CD 45\%CD31+ LSP cells, CD45/CD31+/VEGFR2- LSP cells, CD $45^{\circ} / \mathrm{CD} 31^{+} / \mathrm{VEGFR} 2^{+}$LSP cells, CD $45^{-}$lung MP cells and CD $45^{-} / \mathrm{CD} 31^{+} \mathrm{LMP}$ cells for all experiments. The following six parameters were used to discriminate cells in the experiments: Hoechst 33342 (red), Hoechst 33342 (blue), forward scatter, side scatter, PerCP-Cy5.5-CD45, FITC-SCA1 and PE-CD31 reactivity (green) as previously described $(14,27,30)$. This protocol is illustrated in Fig. 1. The Hoechst dye was excited at $350 \mathrm{~nm}$. A 488-nm argon laser was employed for exciting PerCP-Cy5.5, PE and FITC, and a 633-nm HeNe laser was used for APC. Data analysis was performed using Summit $^{\mathrm{TM}}$ V5.2 software (Beckman Coulter, Inc.).

Primary cell cultures. The murine CD $45^{-} / \mathrm{CD} 31^{+} / \mathrm{VEGFR} 2$ and $\mathrm{CD} 45^{-} / \mathrm{CD} 31^{+} / \mathrm{VEGFR} 2^{+} \mathrm{LSP}$ cells were cultured on fibronectin-coated 8 -well chamber slides $(10,000$ cells/well; Nunc; Sigma-Aldrich; Merck KGaA) at $37^{\circ} \mathrm{C}$ under $5 \% \mathrm{CO}_{2}$ as previously described $(24,28)$. To promote endothelial cell growth and differentiation, the murine CD $45{ }^{-} / \mathrm{CD} 31^{+} / \mathrm{VEGFR} 2$ and $\mathrm{CD} 45^{-} / \mathrm{CD} 31^{+} / \mathrm{VEGFR} 2^{+} \mathrm{LSP}$ cells were cultured at $37^{\circ} \mathrm{C}$ with a defined endothelial differentiation medium (EGM-2) from Cambrex (Baltimore, MA, USA) supplemented with $100 \mathrm{U} / \mathrm{ml}$ of penicillin (Invitrogen; Thermo Fisher Scientific, Inc., Waltham, MA, USA) and $100 \mu \mathrm{g} / \mathrm{ml}$ of streptomycin (Invitrogen; Thermo Fisher Scientitic, Inc.). Following 14 days in culture, the cells were collected for reverse-transcription quantitative polymerase chain reaction (RT-qPCR) and immunostaining analyses, respectively. To examine the association between $\mathrm{CD} 45^{-} / \mathrm{CD} 1^{+} / \mathrm{VEGFR} 2^{-}$andCD $45^{-} / \mathrm{CD} 31^{+} / \mathrm{VEGFR}^{+}$ LSP cells, the CD45/CD31+/VEGFR2- LSP cells were cultured in the same conditions mentioned above for 2 days and then collected for RT-qPCR analysis.

To promote smooth muscle growth and differentiation, the CD45\%CD31+/VEGFR2- LSP cells were cultured with a defined smooth muscle differentiation medium (SmGm-2) from Cambrex supplemented with $100 \mathrm{U} / \mathrm{ml}$ of penicillin (Invitrogen; Thermo Fisher Scientific, Inc.), and $100 \mu \mathrm{g} / \mathrm{ml}$ 


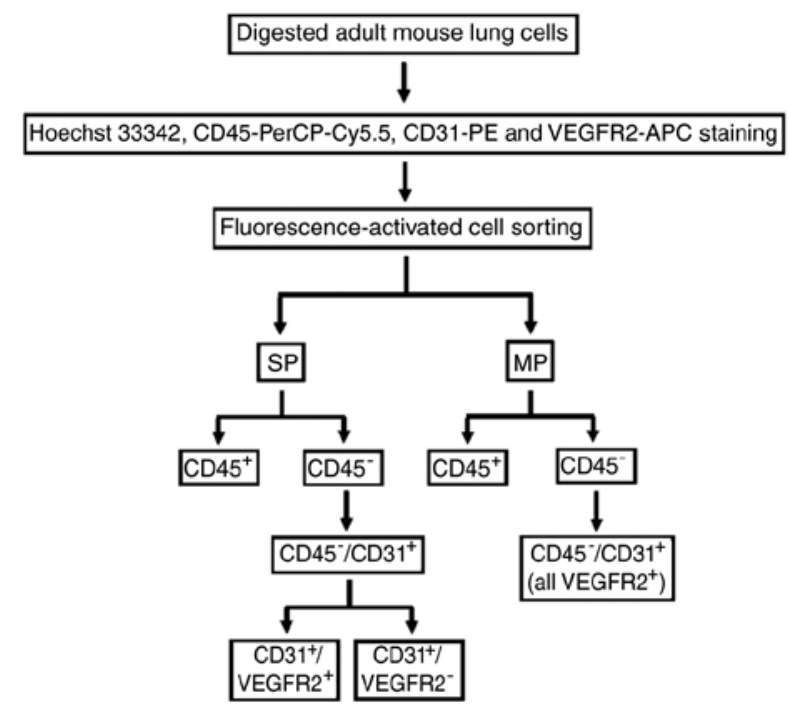

Figure 1. Flow chart illustrating the protocol used in the present study to isolate $\mathrm{CD} 45 / \mathrm{CD} 31^{+} / \mathrm{VEGFR} 2^{-}$and $\mathrm{CD} 45^{-} / \mathrm{CD} 31^{+} / \mathrm{VEGFR} 2^{+}$lung SP cells and $\mathrm{CD} 45 / \mathrm{CD} 31^{+}$cells from adult mouse lungs. VEGFR2, vascular endothelial growth factor receptor 2; SP, side population; MP, main population.

of streptomycin (Invitrogen; Thermo Fisher Scientific, Inc.). The culture medium was replaced every 2 days. Following 14 days in culture, the cells were collected for RT-qPCR and immunostaining analyses. To determine whether the CD $45 / \mathrm{CD} 31^{+} / \mathrm{VEGFR}^{+}$LSP cells were able to differentiate into smooth muscle cells, they were cultured in the medium described above for 14 days and were then harvested for RT-qPCR analysis.

Cell line culture. The HepG2 human liver cancer cell line, obtained from American Type Culture Collection (Manassas, VA, USA), was cultured in Dulbecco's modified Eagle's medium (DMEM) supplemented with $10 \%$ GIBCO $^{\circledR}$ fetal calf serum, $100 \mathrm{U} / \mathrm{ml}$ of penicillin, and $100 \mu \mathrm{g} / \mathrm{ml}$ of streptomycin (all from Invitrogen; Thermo Fisher Scientific, Inc.) at $37^{\circ} \mathrm{C}$ in a $5 \% \mathrm{CO}_{2}$ incubator.

Cellular uptake of Dil-labeled acetylated low-density lipoprotein (Dil-Ac-LDL). The CD $45 / \mathrm{CD} 31^{+} \mathrm{LSP}$ cells at a density of 7,000 cells/well were incubated with EGM-2 containing $10 \mathrm{mg} / \mathrm{ml}$ of Dil-Ac-LDL (Molecular Probes; Thermo Fisher Scientific, Inc.) at $37^{\circ} \mathrm{C}$ for $8 \mathrm{~h}$ as previously described (28). Following washing with PBS, the cells were fixed and nuclei were counterstained with 4-6-diamidino-2-phenylindol-dihydrochloride (DAPI). The slides were examined using an Olympus-DP70 microscope and images were captured with a digital camera (BX51; Olympus Corporation, Tokyo, Japan). HepG2 cells were included to provide a negative control for Ac-LDL uptake.

Methylcellulose assay (colony-forming unit assay). The CD $45^{\circ} / \mathrm{CD} 31^{+}$LSP and LMP cells $(7,000$ cells $/ \mathrm{ml})$ were cultured in Methocult GF M3534 medium according to the manufacturer's protocol (StemCell Technologies, Inc., Vancouver, Canada) as described previously $(17,19,27,28)$. Cell colonies, consisting of $>30$ cells, were scored after 14 days in culture. The cell colonies were fixed with $4 \%$ paraformaldehyde and stained with crystal violet based on the manufacturer's protocol (Sigma-Aldrich; Merck KGaA). Photomicrographs were obtained, from which the colonies were counted using an Olympus-DP70 microscope and images were captured with a digital camera (BX51). In order to determine whether the cells retained their CD $45 / \mathrm{CD} 31^{+}$LSP phenotype, Methoult medium was cut into sections and these were incubated with DMEM at $37^{\circ} \mathrm{C}$ with agitation for $30 \mathrm{~min}$. When the Methocult medium had dissolved in the DMEM, the cells were collected, labeled with the CD45-PerCP-Cy5.5 (1:100), CD31-PE (1:100) and SCA1-FITC (1:100) antibodies, and analyzed by FACS.

$R T-q P C R$ analysis. Total RNA was extracted from the freshly isolated distinct LSP, LMP and cultured cells using an RNAeasy-Mini kit, following the manufacturer's protocol (Qiagen GmbH, Hilden, Germany). Complementary DNA was generated using an M-MLV MicroRNA Reverse Transcription kit (Promega Corporation, Madison, WI, USA). RT-qPCR analysis was performed as previously described using a Rotor-gene 3000 machine (Corbett; Qiagen $\mathrm{GmbH}$ ) with a SYBR-Green qPCR-SuperMix-UDG kit (Thermo Fisher Scientific, Inc.) following the manufacturer's protocol. Commercial primer sets were obtained from Qiagen $\mathrm{GmbH}$, as follows: ATP-binding cassette super-family $\mathrm{G}$ member 2 (ABCG2; cat. no. QT00173138), CD133 (cat. no. QT01065162), VEGFR2 (cat. no. QT00097020), von Willebrand factor (vWF; cat. no. QT00116795), $\alpha$-smooth muscle tropomyosin ( $\alpha$ SMT; cat. no. QT00137354), $\alpha$-smooth muscle actin ( $\alpha$ SMA; cat. no. QT0006746), CD44 (cat. no. QT00173404), myosin heavy chain (cat. no. QT01558130) and $\beta$-actin (cat. no. QT01136772). qPCR was performed in a $20-\mu 1$ reaction system, which contained $10 \mu \mathrm{l}$ SYBR-Green qPCR-SuperMix-UDG (Thermo Fisher Scientific, Inc.), $2 \mu \mathrm{l}$ cDNA, $0.4 \mu \mathrm{l}$ each primer and $7.2 \mu \mathrm{l}$ RNase-free $\mathrm{H}_{2} \mathrm{O}$. The thermal cycler conditions were performed as follows: Cycle 1 $\left(95^{\circ} \mathrm{C}\right.$ for $3 \mathrm{~min}$ ), Cycle $2\left(35\right.$ cycles of $95^{\circ} \mathrm{C}$ for $30 \mathrm{sec}, 57^{\circ} \mathrm{C}$ for $30 \mathrm{sec}, 72^{\circ} \mathrm{C}$ for $30 \mathrm{sec}$ ), Cycle $3\left(72^{\circ} \mathrm{C}\right.$ for $\left.4 \mathrm{~min}\right)$, which was based on the manufacturer's protocol (31). All samples were amplified in triplicate. Amplification data were analyzed with Corbett Rotor-gene 3000 software (Qiagen $\mathrm{GmbH}$ ) as described previously $(27,28)$. The relative mRNA expression levels of the genes mentioned above were normalized against the expression of housekeeper gene $\beta$-actin and calculated using the $2^{-\triangle \Delta C q}$ method as previously described $(28,31,32)$. Gene expression data are presented in relative units.

Immunofluorescence staining of isolated and cultured cells. For analysis of the sorted cells, 1,000 CD45/CD31+/VEGFR2 LSP cells, CD $45^{-} / \mathrm{CD} 31^{+} / \mathrm{VEGFR}^{+}{ }^{+} \mathrm{LSP}$ cells and CD $45^{-}$LMP cells were collected onto positively charged slides by cyto-centrifugation at $60 \mathrm{x} \mathrm{g}$ for $5 \mathrm{~min}$ at room temperature prior to air-drying. The slides were then fixed for $10 \mathrm{~min}$ in $4 \%$ paraformaldehyde/PBS, washed with 1X PBS, air dried and stored at $4^{\circ} \mathrm{C}$ prior to staining. The cultured monolayer cells were fixed and prepared for staining using the same procedure. Immunofluorescence staining was performed as previously described (14). Autofluorescence was first quenched with $10 \mathrm{mM}$ sodium borohydride for $30 \mathrm{~min}$ at room temperature. Nonspecific binding was blocked by incubating with $1 \%$ rabbit serum (cat. no. ab7356; Abcam, Cambridge, MA, USA) or 

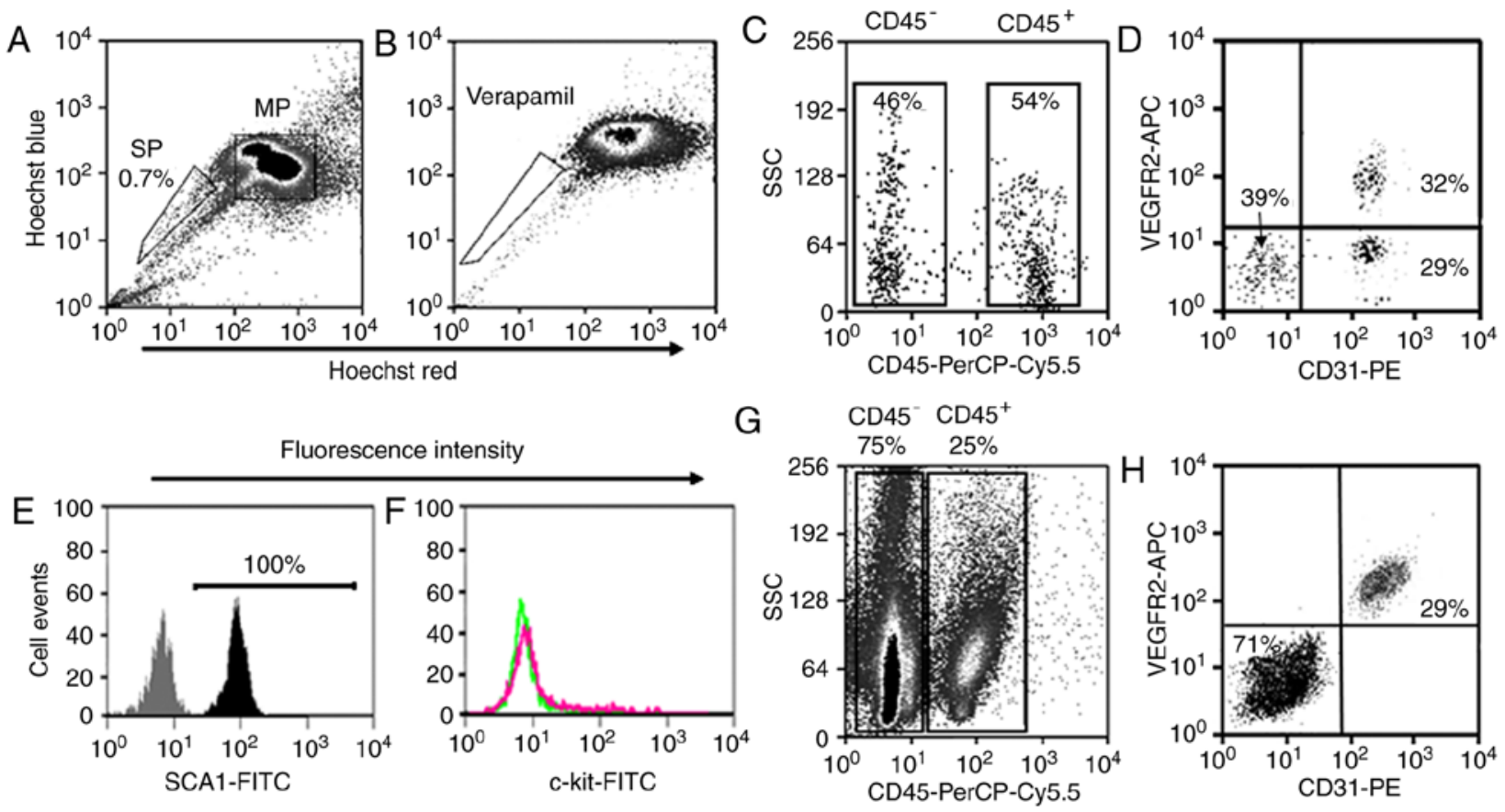

Figure 2. Analysis and isolation of LSP and LMP cells from the adult mouse lung by fluorescence-activated cell sorting. (A) Lung SP cells (outlined to lower left) representing $\sim 0.7 \%$ of the total heart cell population and MP cells (outlined to right) were identified based upon their intensity of Hoechst staining. (B) SP cells disappeared when cells were labeled in the presence of verapamil pretreatment, which inhibits the transporter (outlined to lower left). (C) Based on the expression of CD45, LSP cells were divided into CD45 ${ }^{+}$and CD45 representing $~ 54$ and $46 \%$ of the total LMP cells, respectively. (D) According to expression of CD31 and VEGFR2, CD45 LSP cells were further separated into CD45 $/ \mathrm{CD} 31^{+} / \mathrm{VEGFR} 2{ }^{-}, \mathrm{CD}^{-} 5^{\circ} / \mathrm{CD} 31^{+} / \mathrm{VEGFR} 2^{+}$and $\mathrm{CD} 45^{-} / \mathrm{CD} 31^{-} / \mathrm{VEGFR} 2^{-}$, representing $\sim 29,32$ and $39 \%$ of the total LSP cells, respectively. CD45/CD31 ${ }^{+}$LSP cells (including CD45/CD31 ${ }^{+} / \mathrm{VEGFR} 2^{-}$and $\mathrm{CD} 45^{-} / \mathrm{CD}^{-} 1^{+} / \mathrm{VEGFR} 2^{+}$ LSP cells) were stained with FITC-conjugated (E) SCA1 and (F) c-kit antibody (black and red respectively) or its isotype control (gray and green respectively), showing $100 \%$ positive for SCA1 and negative for c-kit. (G) LMP cells were separated into CD45 (25\% of total LMP) and CD45 (75\% of total LMP) cells and $(\mathrm{H})$ further divided into $\mathrm{CD} 45^{\circ} / \mathrm{CD} 31^{+} / \mathrm{VEGFR} 2^{+}$and $\mathrm{CD} 45^{\circ} / \mathrm{CD} 31^{-} / \mathrm{VEGFR} 2^{-} \mathrm{LMP}$ cells. SP, side population; MP, main population; LSP, lung SP; LMP, lung MP; VEGFR2, vascular endothelial growth factor receptor 2; SCA1, stem cell antigen-1.

goat serum (cat. no. ab7487; Abcam). The primary antibodies used included monoclonal rat anti-mouse ABCG2 (1:100; cat. no. ab24115; Abcam), polyclonal rabbit anti-mouse vWF (1:100; cat. no. AB7356; Chemicon, Temecula, CA, USA), monoclonal anti-mouse $\alpha$ SMA-Cy3 (1:100; cat. no. C-6198; Sigma-Aldrich; Merck KGaA) and polyclonal rabbit anti-mouse $\alpha$ SMT $(1: 100$; cat. no. T3651; Sigma-Aldrich; Merck KGaA). Secondary antibodies included rabbit anti-rat IgG-FITC (1:200; cat. no. ab6730-1; Abcam), goat anti-rabbit IgG-594 (1:200; cat. no. A11012; Invitrogen; Thermo Fisher Scientific, Inc.) and donkey anti-rabbit IgG-FITC (1:200; cat. no. A21206; Invitrogen; Thermo Fisher Scientific, Inc.). All incubations of primary and secondary antibodies were performed for 60 and $30 \mathrm{~min}$ at $4^{\circ} \mathrm{C}$ in the dark, respectively. The nuclei were counterstained with DAPI. Slides were examined using an Olympus-DP70 microscope and images were captured with a digital camera (BX51).

Statistical analysis. Data are presented as the mean \pm standard deviation. Student's t-test (two-tailed unpaired) was used to analyze experimental data containing two groups, and one-way analysis of variance with the Bonferroni post hoc test was used to analyze experimental data with $\geq 3$ groups. Statistical analysis was performed using SPSS version 16.0 (SPSS, Inc., Chicago, IL, USA). P $<0.05$ was considered to indicate a statistically significant difference. Each experiment was repeated three times to obtain the means used for statistical analysis ( $n=3$ experiments) as previously described (28).

\section{Results}

\section{LSP cell populations}

Identification, isolation and gene expression. The adult mouse lungs were enzymatically digested into single cell suspensions and subjected to FACS analysis (Fig. 1). The LSP cells were detected on density dot plots based on their capacity to efflux Hoechst 33342 dye. Those cells that were weakly labeled for Hoechst 33342 dye (LSP cells) represented $\sim 0.7 \%$ of the total cell population (Fig. $2 \mathrm{~A}$ ). The LSP population disappeared when the ABCG2 transporter was blocked with verapamil (Fig. 2B). The LSP cells were first separated into $\mathrm{CD}^{4} 5^{+}\left(\sim 54 \%\right.$ of total LSP cells) and CD $45^{-}(\sim 46 \%$ of total LSP cells) subpopulations as previously described (14) (Fig. 2C). Based on the expression of CD31, the CD45- LSP cells were further divided into $\mathrm{CD} 45^{\circ} / \mathrm{CD}^{-} 1^{-} \mathrm{LSP}$ cells $(\sim 39 \%$ of total CD45 ${ }^{-}$LSP cells) and CD $45^{\circ} / \mathrm{CD}^{+} 1^{+} \mathrm{LSP}$ cells $(\sim 61 \%)$. According to expression of VEGFR2, CD $45^{-/ C D} 31^{+}$LSP cells were further separated into CD45/CD31//VEGFR2- ( 29\% of total CD $45^{-}$LSP cells) and CD $45^{-} / \mathrm{CD} 31^{+} / \mathrm{VEGFR}^{+} \mathrm{LSP}$ cells ( 32\%) (Fig. 2D). All CD45 $/ \mathrm{CD} 31^{+}$LSP cells (VEGFR2and VEGFR $2^{+}$) expressed SCA1, but none expressed c-kit (Fig. 2E and F). Using the same surface markers, the LMP cells were separated into $\mathrm{CD} 45^{+}$and $\mathrm{CD}^{-} 5^{-}$subpopulations, which were further divided into CD45/CD31\%/VEGFR2and $\mathrm{CD} 45^{-} / \mathrm{CD} 31^{+} / \mathrm{VEGFR} 2^{+}$LMP cells. Notably, all CD $45 \%$ CD $31^{+}$LMP cells were VEGFR2 ${ }^{+}$(Fig. $2 \mathrm{G}$ and $\mathrm{H}$ ). Based on their immune-phenotype, CD $45 \%$ CD $31^{+} \mathrm{LSP}$, 
A

$\square$ Freshly isolated CD $31^{+}$NEGFR2 ${ }^{-}$LSP
$\square$ Freshly isolated CD $31^{+}$NEGFR2 ${ }^{+}$LSP
Freshly isolated CD $45^{-}$LMP
UD=Undetectable
${ }^{*} \mathrm{p}<0.05$
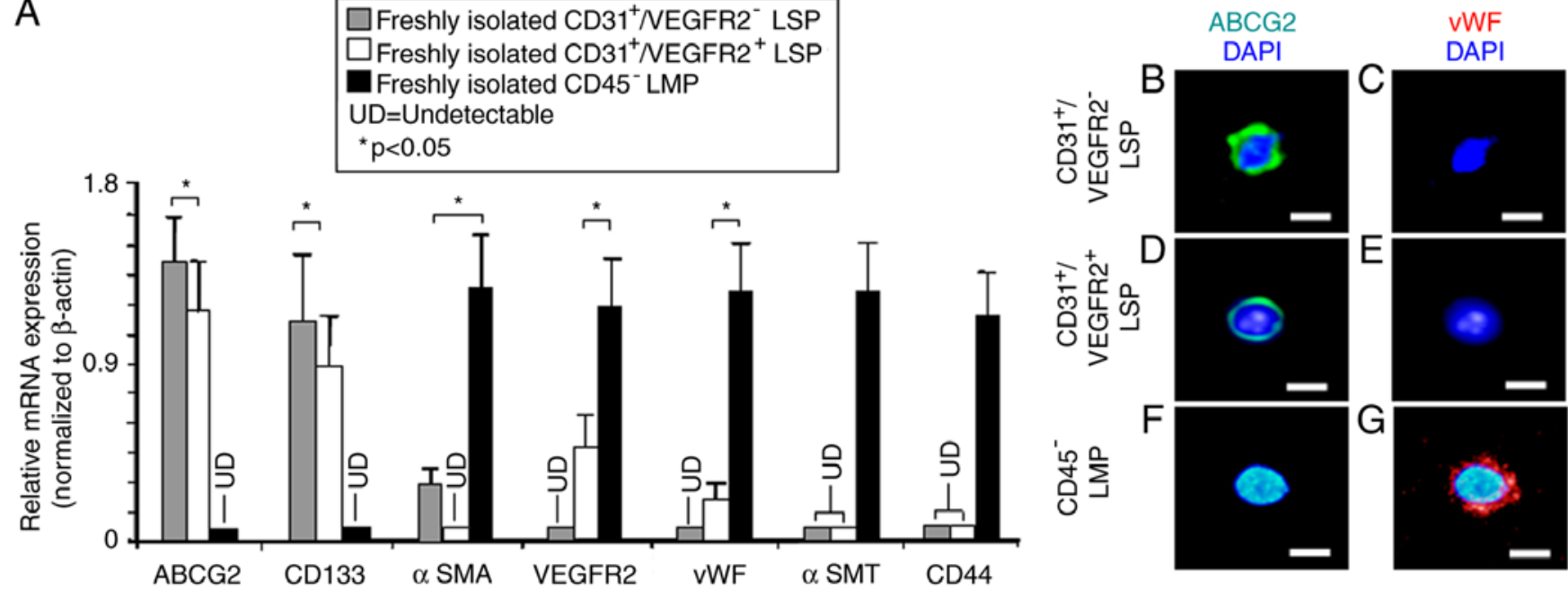

Figure 3. Gene expression in sorted LSP and LMP cells. Expression of markers for stem cells (ABCG2), endothelial progenitors (CD133), early smooth muscle ( $\alpha$ SMA), endothelial cells (VEGFR2), mature endothelial cells (vWF), mature smooth muscle cells ( $\alpha$ SMT) and mesenchymal cells (CD44) were compared among sorted populations of cells. (A) Reverse transcription-quantitative polymerase chain reaction analysis compared relative mRNA expression levels in CD45/CD31 ${ }^{+} /$VEGFR2 (grey bar) and CD45/CD31 ${ }^{+} /$VEGFR2 $2^{+}$LSP (white bar) cells. CD45 LMP cells (black bar) were used as a control. For immunofluorescent labeling of cells, following sorting, CD $45 /$ CD $31^{+} / \mathrm{VEGFR}^{+}{ }^{+}$and CD $45 / \mathrm{CD} 31^{+} / \mathrm{VEGFR} 2{ }^{-}$LSP cells and CD $45^{-}$LMP cells were cytospun onto glass slides. Nuclei (blue) were counterstained with DAPI. CD45/CD31 /VEGFR2 LSP cells were immunopositive for (B) ABCG2 (green), but not (C) vWF (red). Similarly, CD45/CD31 ${ }^{+} / \mathrm{VEGFR}^{+}{ }^{2}$ LSP cells were positive for (D) ABCG2 (green), but not for (E) vWF (red). By contrast, CD45 LMP cells were not immunopositive for (F) ABCG2 (green) but were for (G) vWF (red). Scale bar, $30 \mu \mathrm{m}$. Data are presented as the mean \pm standard deviation (n=3 experiments); "P<0.05; UD, undetectable; LSP, lung side population; LMP, lung main population; ABCG2, ATP-binding cassette super-family G member 2; VEGFR2, vascular endothelial growth factor receptor 2; vWF, von Willebrand factor; $\alpha$ SMT, $\alpha$-smooth muscle tropomyosin; $\alpha$ SMA, $\alpha$-smooth muscle actin; DAPI, 4-6-diamidino-2-phenylindol-dihydrochloride.
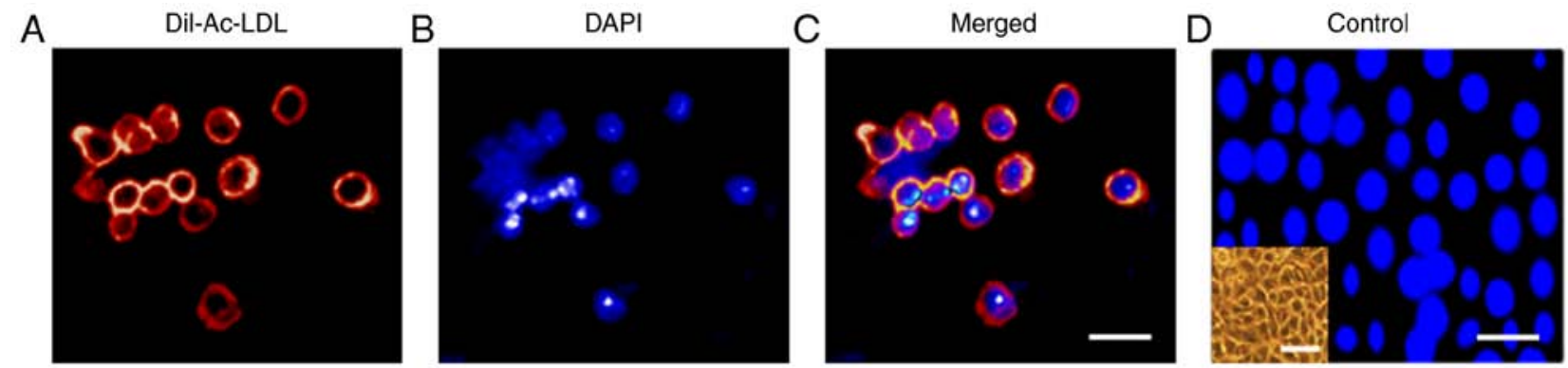

Figure 4. Representative photomicrograph field showing Dil-Ac-LDL uptake by CD45/CD31 ${ }^{+}$LSP cells (including CD45 $/$CD $31^{+} /$VEGFR $2^{-}$and CD $45 /$ CD $31^{+} /$VEGFR2 ${ }^{+}$LSP cells). (A) CD45/CD31 ${ }^{+}$LSP cells demonstrating cellular uptake of Dil-Ac-LDL. (B) DAPI fluorescence channel, showing nuclei. (C) Merged fluorescence channels. Scale bar, $30 \mu \mathrm{m}$. (D) HepG2 cells, which did not take up Dil-Ac-LDL, served as a negative control. Scale bar, $30 \mu \mathrm{m}$. The inset on the lower left shows a phase contrast image of the cultured HepG2 cells (scale bar, $60 \mu \mathrm{m}$ ). VEGFR2, vascular endothelial growth factor receptor 2; LSP, lung side population; Dil-Ac-LDL, Dil-labeled acetylated low-density lipoprotein; DAPI, 4-6-diamidino-2-phenylindol-dihydrochloride.

CD45/CD31+/VEGFR2- LSP, CD45\%CD31+/VEGFR2 ${ }^{+}$LSP, $\mathrm{CD} 455^{-} \mathrm{LMP}$ and $\mathrm{CD} 45 \% \mathrm{CD} 31^{+} \mathrm{LMP}$ cells were isolated by FACS (Fig. 2).

In our previous study, it was found that CD31+ CSP cells are endothelial progenitors of adult mouse heart (27). Therefore, the present study aimed to further characterize CD $45 / \mathrm{CD} 31^{+/} / \mathrm{VEGFR} 2-$ and CD $45 / \mathrm{CD} 31^{+/ \mathrm{VEGFR}} 2^{+} \mathrm{LSP}$ cells by examining the expression of genes specific for stem/progenitor cells and endothelial cells, using RT-qPCR analysis. As expected, the CD $45^{-} / \mathrm{CD} 31^{+} / \mathrm{VEGFR} 2^{-}$and CD $45 \%$ CD $31^{+} / \mathrm{VEGFR} 2^{+}$LSP cells expressed high mRNA levels of the $\mathrm{ABCG} 2$ transporter, which is responsible for the efflux of Hoechst 33342 dye (20). Both also expressed CD133, a marker for endothelial progenitor cells (33). By contrast, the CD45- LMP cells expressed neither ABCG2 nor CD133. VEGFR2, a marker of endothelial cells, and
vWF, a mature endothelial cell marker, were just detectable in the $\mathrm{CD} 45^{-} / \mathrm{CD} 31^{+} / \mathrm{VEGFR}^{+} \mathrm{LSP}$ cells but not in the CD45/CD31+/VEGFR2- LSP cells (Fig. 3A). CD45- LMP cells, serving as a positive control, expressed high levels of VEGFR2 and vWF (Fig. 3A). The CD45 LMP cells also expressed high levels of mRNAs encoding $\alpha$ SMA, a marker of smooth muscle progenitors $(24,34), \alpha$ SMT, a marker of mature smooth muscle cells $(24,34)$ and CD44, a marker of mesenchymal cells. By contrast, the expression of $\alpha$ SMA was low (but detectable) in the CD45/CD31 $/$ VEGFR2 LSP cells and completely undetectable in the CD $45^{-} / \mathrm{CD} 31^{+} / \mathrm{VEGFR} 2^{+} \mathrm{LSP}$ cells, indicating that CD $45 / \mathrm{CD} 31^{+} /$VEGFR 2 LSP cells may be smooth muscle progenitors, whereas CD45/CD31 $/$ VEGFR2 $2^{+}$ LSP cells are not. In the CD $45 \%$ CD $31^{+} /$VEGFR $2-$ and the $\mathrm{CD} 45 / \mathrm{CD} 31^{+} / \mathrm{VEGFR} 2^{+}$LSP cells, no expression of aSMT and CD44 was detectable (Fig. 3A), suggesting 

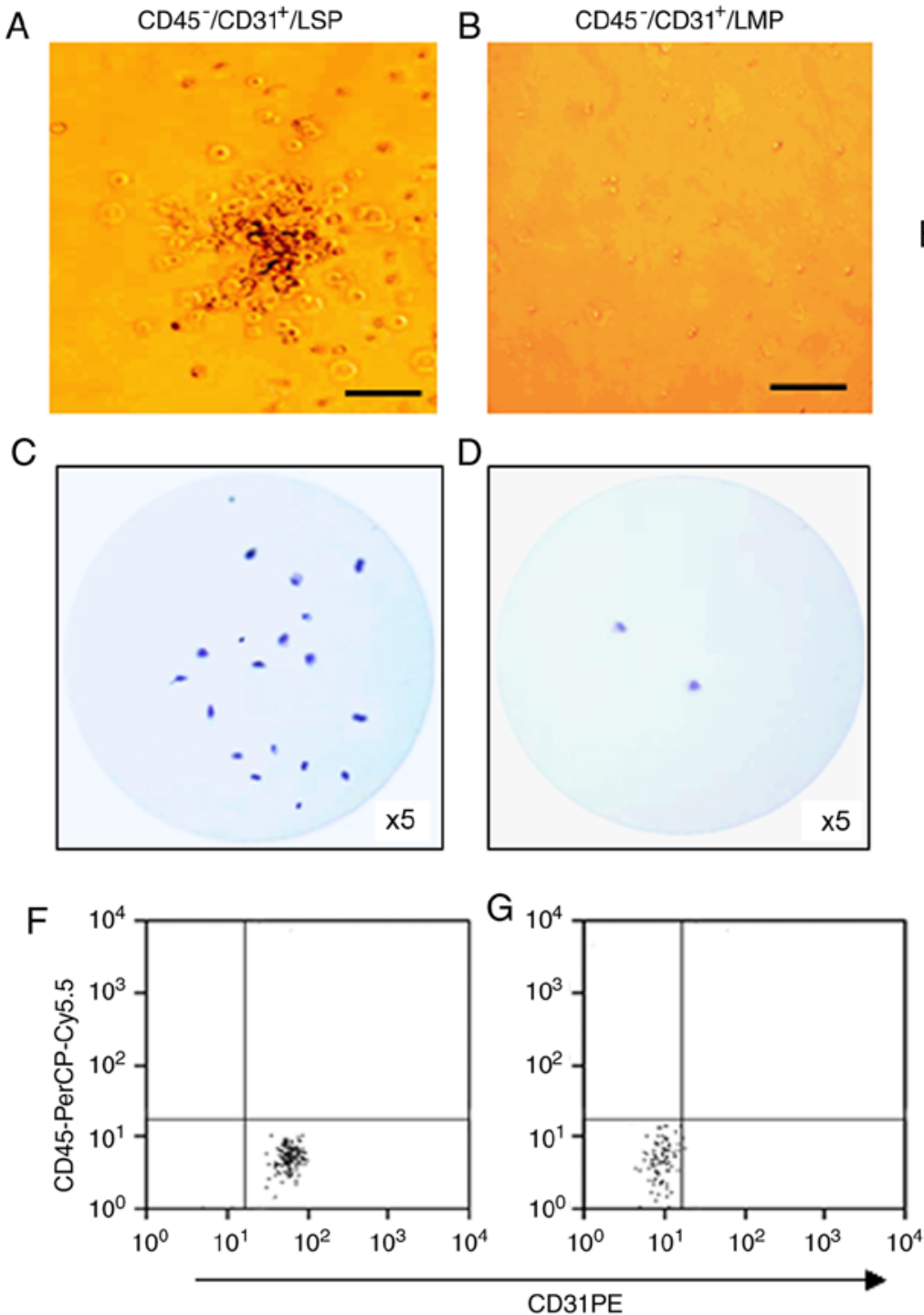

$\mathrm{E}$
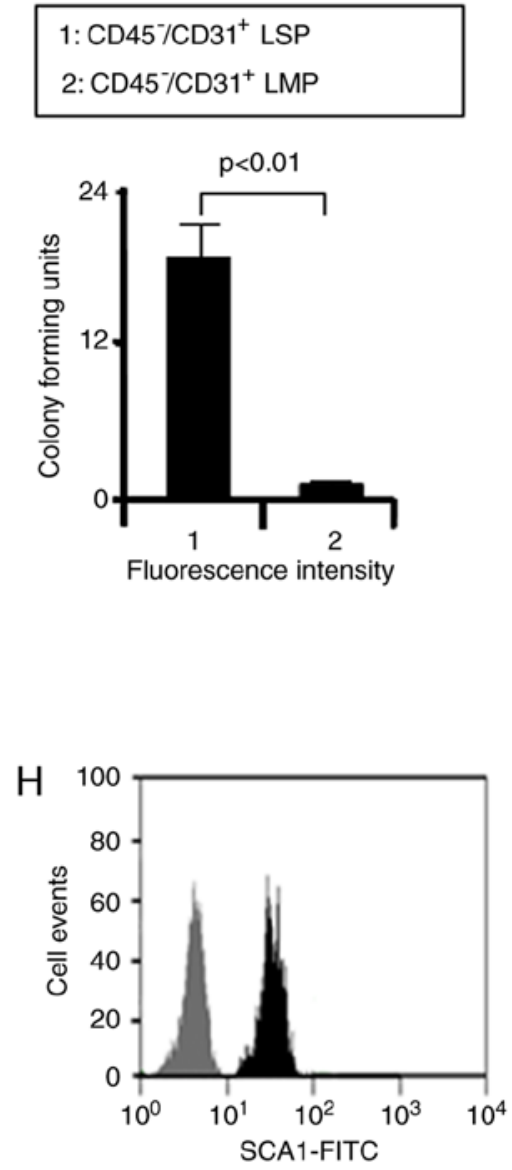

Figure 5. Colony formation by CD $45^{-} / \mathrm{CD} 31^{+}$LSP cells. (A) Representative colony formed by CD $45^{-} / \mathrm{CD} 31^{+}$LSP cells in methylcellulose medium, visualized by phase contrast microscopy (scale bar, $50 \mu \mathrm{m}$ ). (B) Representative image of a field of CD $45^{-} / \mathrm{CD} 31^{+}$LMP cells (scale bar, $50 \mu \mathrm{m}$ ). Representative, low magnification images of colony formation by (C) CD $45^{\circ} / \mathrm{CD} 31^{+} \mathrm{LSP}$ cells and (D) LMP cells cultured in methylcellulose medium and stained with crystal violet (x 5 magnification). (E) Graph showing the ratio of colonies formed by CD45/CD31 ${ }^{+}$LSP cells, compared to CD45/CD31 $1^{+} \mathrm{LMP}$ cells (P<0.01). (F) Colony-forming cells subsequently isolated from methylcellulose media, labeled with CD45-PerCP-Cy5.5 and CD31-PE, and analyzed by flow cytometry, with the results for the (G) isotype control. (H) Colony-forming cells isolated from methocult media labeled with SCA1-FITC (black) or its isotype antibody (grey) and analyzed by flow cytometry. Data are presented as the mean \pm standard deviation ( $\mathrm{n}=3$ experiments). LSP, lung side population; LMP, lung main population.

that neither the CD45/CD31+/VEGFR2- LSP cells nor the CD $45 \% / \mathrm{CD}^{2} 1^{+} / \mathrm{VEGFR} 2^{+}$LSP cells are mature smooth muscle or mesenchymal cells.

Subsequently, the CD45/CD31+/VEGFR2- LSP, CD45\% $\mathrm{CD} 1^{+} / \mathrm{VEGFR}^{+}{ }^{+} \mathrm{LSP}$ and CD45- ${ }^{-} \mathrm{LMP}$ cells were collected onto duplicate glass slides (1,000 cells/slide) and antibody probes were used to examine the expression of proteins. The immunostaining confirmed that the CD $45 \%$ CD $31^{+} / \mathrm{VEGFR} 2$ LSP and $\mathrm{CD}^{2} 5^{-} / \mathrm{CD} 31^{+} / \mathrm{VEGFR} 2^{+}$LSP cells expressed the $\mathrm{ABCG} 2$ transporter protein, but not the $\mathrm{vWF}$ protein (Fig. 3B-E). By contrast, the CD45- LMP cells expressed vWF protein, but not the ABCG2 transporter (Fig. 3F and G). Based on the mRNA analysis, the high expression of CD133, low expression of $\alpha \mathrm{SMA}$, and absence of VEGFR2, vWF, $\alpha \mathrm{SMT}$ and CD44, suggested that CD45\%CD31 ${ }^{+} /$VEGFR2- LSP cells may be progenitors for endothelial and smooth muscle cells, but not progenitors for mesenchymal cells. By contrast, the high expression of CD133, low (detectable) expression of VEGFR2 and $v W F$, and absence of $\alpha$ SMA, $\alpha$ SMT and CD44 indicate that CD $45 \% / C D 31^{+} / V_{E G F R}{ }^{+}$LSP cells may be late-commitment endothelial progenitors. Taken together, these results indicate that CD $45 \%$ CD $31^{+} / \mathrm{VEGFR} 2^{-}$and $\mathrm{CD} 45 \% \mathrm{CD} 31^{+} / \mathrm{VEGFR} 2^{+}$ LSP cells may be endothelial progenitor cells. The finding that CD $45 \% / C D 31^{+}$LSP cells, including CD45\%/CD31+/VEGFR2 and $\mathrm{CD} 45 \% \mathrm{CD} 31^{+} / \mathrm{VEGFR} 2^{+}$LSP cells, take up DiI-Ac-LDL (Fig. 4A-D) supports this notion.

In vitro colony-formation by $C D 45^{-} / C D 31^{+}$LSP cells. Our previous study showed that $\mathrm{CD} 31^{+} \mathrm{CSP}$ cells were able to form colonies in vitro (27). Therefore, the present study examined the in vitro colony-forming potential of $\mathrm{CD} 45^{-} / \mathrm{CD} 31^{+} \mathrm{LSP}$ cells. LMP and LSP cells freshly isolated from adult murine lungs were plated on methylcellulose media. After 14 days in culture, the number of colonies was counted. A typical colony formed 

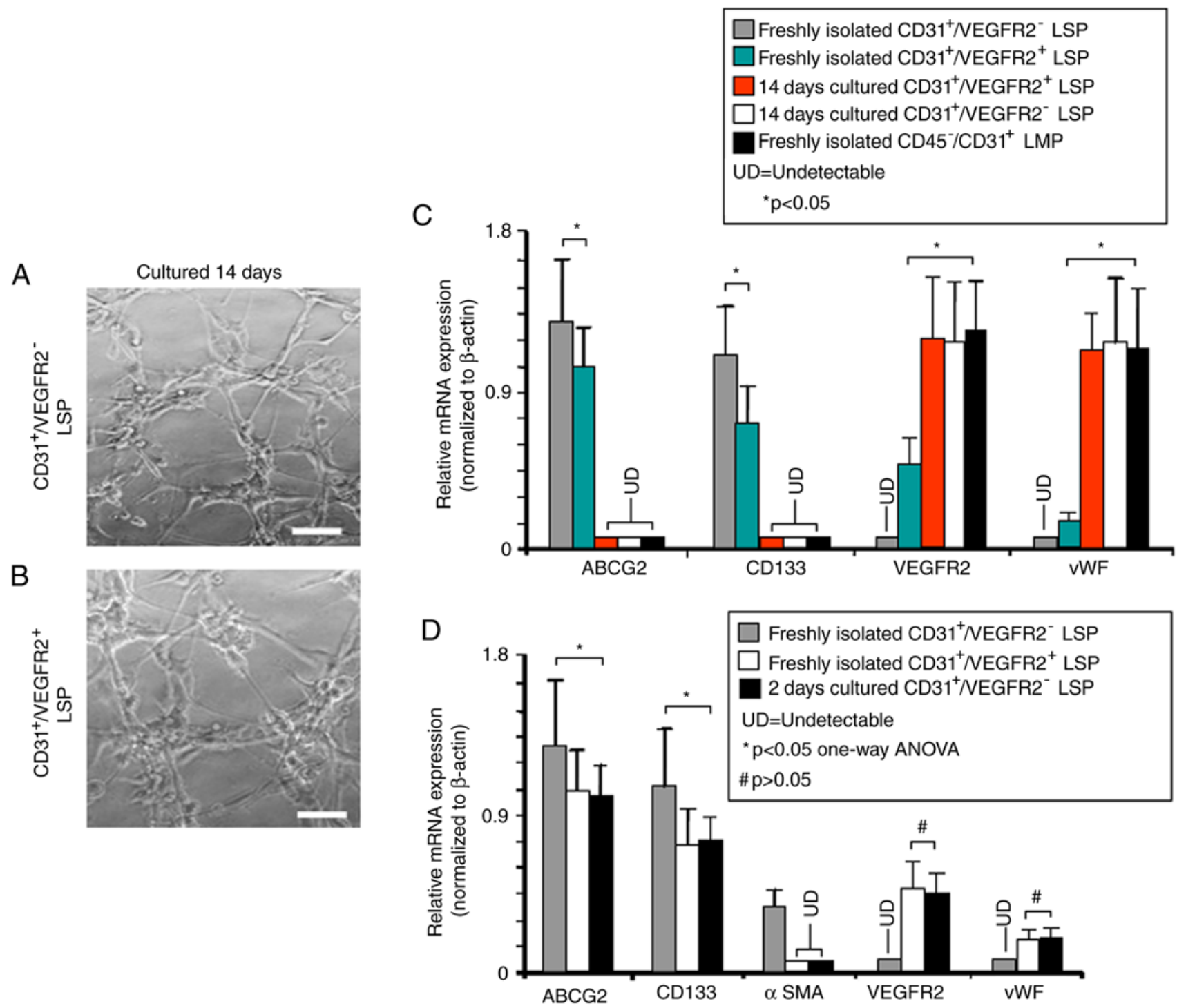

Figure 6. In vitro endothelial differentiation by CD45/CD31+/VEGFR2 ${ }^{-}$and CD45/CD31 $/$VEGFR2 $2^{+}$LSP cells. Representative photomicrographs show vascular tube-like networks formed by (A) CD $45 / \mathrm{CD} 31^{+} /$VEGFR2 ${ }^{-}$and (B) CD $45 / \mathrm{CD} 31^{+} /$VEGFR2 $2^{+} \mathrm{LSP}$ cells after 2 weeks in culture under endothelial differentiation-inducing conditions (scale bar, $50 \mu \mathrm{m}$ ). (C) RT-qPCR analysis performed to compare relative expression of mRNAs encoding ABCG2, CD133, VEGFR2 and vWF genes in freshly isolated CD45/CD31 $1^{+} /$VEGFR2- LSP cells (grey bars), CD45/CD31 $/$VEGFR2 ${ }^{+}$LSP cells (green bars), in $\mathrm{CD} 45 / \mathrm{CD} 31^{+} / \mathrm{VEGFR} 2^{+}$LSP cells after 14 days culture (red bar), and in CD45/CD31 $/$ VEGFR $2^{-}$LSP cells after 14 days culture (white bar). Freshly isolated $\mathrm{CD} 45 / \mathrm{CD} 31^{+} \mathrm{LMP}$ cells are included as a control (black bar). (D) RT-qPCR analysis was performed to compare the relative expression of mRNAs encoding ABCG2, CD133, $\alpha$ SMA, VEGFR2 and vWF genes in freshly isolated CD45/CD31 $/$ VEGFR2 LSP (grey bars) CD45/CD31 $/$ VEGFR2 $2^{+}$LSP (white bars), and in CD $45 / \mathrm{CD} 31^{+} /$VEGFR2 - LSP after 2 days culture (black bars). Data are presented as the mean \pm standard deviation ( $\mathrm{n}=3$ experiments; ${ }^{*} \mathrm{P}<0.05 ;{ }^{*} \mathrm{P}>0.05 ; \mathrm{LSP}$, lung side population; LMP, lung main population; UD, undetectable; ABCG2, ATP-binding cassette super-family G member 2; VEGFR2, vascular endothelial growth factor receptor 2; vWF, von Willebrand factor; $\alpha \mathrm{SMA}, \alpha$-smooth muscle actin.

by $\mathrm{CD} 45 \% \mathrm{CD} 31^{+} \mathrm{LSP}$ cells and a typical field of $\mathrm{CD} 45 \% \mathrm{CD} 31^{+}$ LMP cells are shown in Fig. 5A and B, respectively. Compared with the $\mathrm{CD} 45 \% \mathrm{CD} 31^{+} \mathrm{LMP}$ cells, the CD45/CD31 LSP cells produced more colonies (Fig. 5C-E). FACS analysis of the LSP cells that were subsequently isolated from the methylcellulose media revealed surface expression of CD31 (100\%) and SCA1 (100\%), but not CD45, indicating that the colony forming cells had retained their phenotype following culture (Fig. 5F-H). These findings suggest that $\mathrm{CD} 45^{\circ} / \mathrm{CD} 31^{+} \mathrm{LSP}$ cells possess a substantially greater potential for self-renewal in culture compared with LMP cells.

In vitro differentiation of LSP cells. To examine their differentiation potential, CD $45 \%$ CD $31^{+} /$VEGFR $2-$ and
$\mathrm{CD} 45 / \mathrm{CD} 31^{+} / \mathrm{VEGFR} 2^{+} \mathrm{LSP}$ cells were separately isolated and cultured in conditions known to promote the growth and differentiation of either endothelial or smooth muscle cells. Following culture to promote endothelial differentiation for 14 days, the CD $45 \%$ CD $31^{+} /$VEGFR $2-$ and CD $45 / C D 31^{+} / V_{\text {VGFR }}{ }^{+}$LSP cells each formed tube-like vascular networks (Fig. 6A and B), suggesting that they had differentiated into endothelial, or endothelial-like, cells. RT-qPCR analysis was then used to examine the expression of stem/progenitor cell genes vs. endothelial cell-associated genes in freshly-isolated and cultured CD $45 \%$ CD $31^{+} /$VEGFR $2-$ and CD $45 \%$ CD $31^{+} /$VEGFR $2^{+}$ LSP cells. These were compared with freshly isolated CD $45 \%$ CD $31^{+}$LMP cells, which represent mature endothelial cells. ABCG2 and CD133 were expressed in the freshly isolated 
A

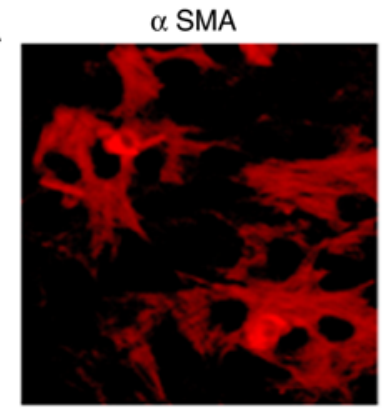

B

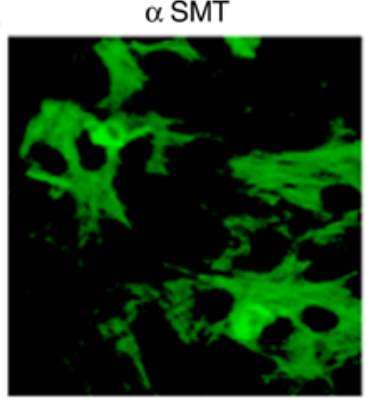

C

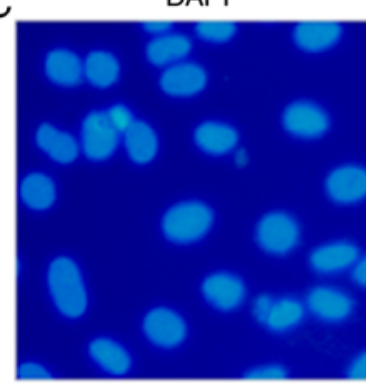

D

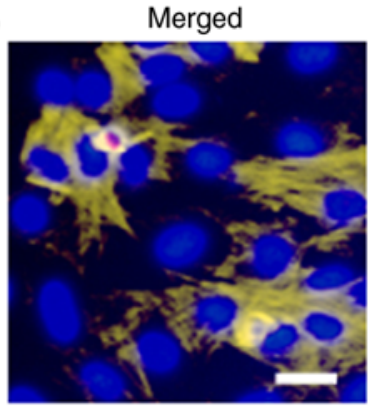

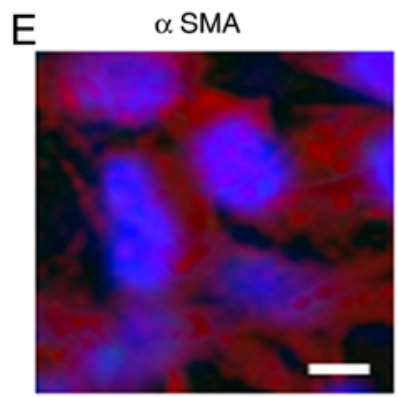

$\alpha$ SMA DAPI
$\mathrm{F}$

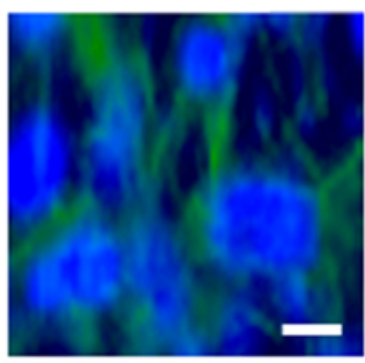

$\alpha$ SMT DAPI

$\square$ Freshly isolated CD $31^{+}$NEGFR2 ${ }^{-}$LSP
$\square$ Freshly isolated CD $31^{+}$NEGFR2 ${ }^{+}$LSP
$\square 14$ days cultured $\mathrm{CD} 31^{+} /$NEGFR2 ${ }^{+}$LSP
$\square 14$ days cultured CD $31^{+} /$NEGFR2 ${ }^{-}$LSP
Freshly isolated CD $45^{-}$LMP
UD=Undetectable
${ }^{*} \mathrm{p}<0.05$

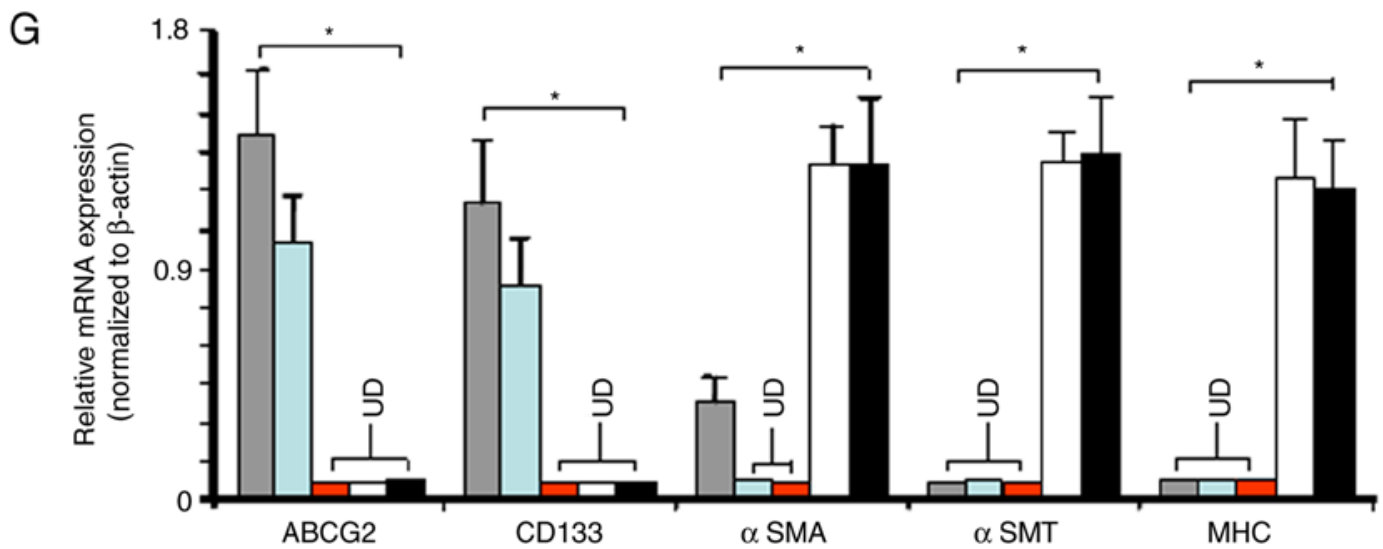

Figure 7. In vitro smooth muscle differentiation potential of CD45/CD31 /VEGFR2 and CD45/CD31 $1^{+} / \mathrm{VEGFR} 2^{+}$LSP cells. Images (scale bar, $20 \mu \mathrm{m}$ ) show the representative microscopic fields of CD45/CD31 $/$ VEGFR2 LSP cells double-labeled for $\alpha$ SMA and $\alpha$ SMT after 14 days in culture under smooth muscle differentiation-inducing conditions; numerous cells stained positively with (A) anti- $\alpha$ SMA antibody (red) and (B) anti- $\alpha$ SMT antibody (green). (C) Nuclei were counterstained with DAPI (blue). (D) Merge of the optical channels. Single immunofluorescence labeling with (E) anti- $\alpha$ SMA (red) and (F) anti- $\alpha$ SMT (green) is shown (scale bar, $10 \mu \mathrm{m}$ ). (G) Reverse transcription-quantitative polymerase chain reaction analysis was performed to compare gene expression by freshly isolated CD $45 / \mathrm{CD} 31^{+} / \mathrm{VEGFR} 2-\mathrm{LSP}$ cells (grey bar), CD $45 \%$ CD $31^{+} / \mathrm{VEGFR} 2{ }^{-} \mathrm{LSP}$ cells after 14 days culture (white bar), freshly isolated $\mathrm{CD}^{\circ} / \mathrm{CD} 31^{+} / \mathrm{VEGFR}^{+}$LSP cells (light blue bar) and CD45/CD31 $/$VEGFR2- LSP cells after 14 days culture (red bar). Freshly isolated CD45 ${ }^{-}$LP cells are included as a control (black bar). Relative expression levels of the ABCG2, CD133, $\alpha$ SMA, $\alpha$ SMT and MHC genes were compared between the three types of cells. Data are presented as the mean \pm standard deviation ( $\mathrm{n}=3$ experiments). "P<0.05; LSP, lung side population; LMP, lung main population; UD, undetectable; ABCG2, ATP-binding cassette super-family G member 2; VEGFR2, vascular endothelial growth factor receptor 2; vWF, von Willebrand factor; $\alpha$ SMT, $\alpha$-smooth muscle tropomyosin; $\alpha$ SMA, $\alpha$-smooth muscle actin; MHC, myosin heavy chain; DAPI, 4-6-diamidino-2-phenylindol-dihydrochloride.

CD $45 \%$ CD $31^{+} /$VEGFR2 - and CD $45 \%$ CD $31^{+} /$VEGFR2 ${ }^{+}$LSP cells, but not in the cultured cells nor in the freshly isolated CD $45 \%$ CD $31^{+}$LMP cells (Fig. 6C). Expression levels of the stem/progenitor markers ABCG2 and CD133 were significantly lower in the freshly isolated CD $45^{-} / \mathrm{CD} 31^{+} / \mathrm{VEGFR} 2^{+}$ LSP cells compared with those in the freshly isolated CD $45^{-/ C D} 31^{+} /$VEGFR2- LSP cells. No expression of endothelial cell markers VEGFR2 and vWF was detected in the freshly isolated CD $45^{-} / \mathrm{CD} 31^{+} / \mathrm{VEGFR} 2^{-}$LSP cells, and their expression was weak in the $\mathrm{CD} 45^{\circ} / \mathrm{CD} 31^{+} / \mathrm{VEGFR} 2^{+} \mathrm{LSP}$ cells However, following culture, the CD $45^{-} / \mathrm{CD} 31^{+} / \mathrm{VEGFR}^{-}$and CD $45 / \mathrm{CD} 31^{+} / \mathrm{VEGFR} 2^{+}$LSP cells the mRNA expression levels of VEGFR2 and vWF were high, at levels indistinguishable from those in the freshly isolated CD $45^{-/ C D} 31^{+}$LMP cells (Fig. 6C). These results further support the hypothesis that CD $45 \% / C D 31^{+} /$VEGFR2 ${ }^{-}$LSPcells andCD45\%/CD31 ${ }^{+} /$VEGFR2 ${ }^{+}$ LSP cells may be endothelial progenitors, similar to our previous findings with SP cells in the mouse heart (27).

The detection of the expression of VEGFR2 and vWF, and relatively low levels of ABCG2, CD133 suggested that $\mathrm{CD} 45^{-} / \mathrm{CD} 31^{+} / \mathrm{VEGFR} 2^{+} \mathrm{LSP}$ cells may be late-commitment endothelial progenitors. To investigate whether $\mathrm{CD} 45^{-} / \mathrm{CD} 31^{+} / \mathrm{VEGFR} 2^{+}$LSP cells may be derived from $\mathrm{CD}^{2} 5^{-} / \mathrm{CD} 31^{+} / \mathrm{VEGFR} 2^{-}$LSP cells, freshly isolated CD $45 \%$ CD $31^{+} /$VEGFR2- LSP cells were cultured for 2 days under conditions to promote endothelial differentiation. 
During this culture, the CD45/CD31+/VEGFR2 LSP cells showed significant reductions in the mRNA expression levels of ABCG2 and CD133, with levels becoming similar to those found in freshly isolated CD $45 / \mathrm{CD} 31^{+} / \mathrm{VEGFR} 2^{+} \mathrm{LSP}$ cells (Fig. 6D). As expected, no expression of endothelial markers VEGFR2 and vWF was detected in the freshly isolated CD $45 \% \mathrm{CD} 31^{+} / \mathrm{VEGFR} 2-\mathrm{LSP}$ cells. However, following 2 days in culture, mRNA expression of VEGFR2 and $\mathrm{vWF}$ was detected in CD45/CD31 ${ }^{+} / \mathrm{VEGFR} 2$ LSP cells at levels comparable with those found in freshly isolated CD $45^{\circ} / \mathrm{CD} 31^{+} / \mathrm{VEGFR}^{+}$LSP cells (Fig. 6D). The freshly isolated $\mathrm{CD} 45 \% \mathrm{CD} 31^{+} / \mathrm{VEGFR} 2-\mathrm{LSP}$ cells expressed the smooth muscle marker, $\alpha$ SMA, however, the expression of $\alpha$ SMA disappeared following 2 days in culture. Therefore, the CD $45 \%$ CD $31^{+} / \mathrm{VEGFR} 2-$ LSP cells came to resemble $\mathrm{CD} 45 \% / \mathrm{CD} 31^{+} / \mathrm{VEGFR} 2^{+}$cells in their pattern of gene expression following 2 days in culture (Fig. 6D). This suggested that the 2-day-cultured $\mathrm{CD} 45 / \mathrm{CD} 31^{+} / \mathrm{VEGFR} 2$ LSP cells and freshly isolated CD $45^{\circ} / \mathrm{CD} 31^{+} /$VEGFR2 $2^{+}$ LSP cells had lost their ability to differentiate into smooth muscle cells, which was consistent with the hypothesis that CD $45 \%$ CD $31^{+} / \mathrm{VEGFR}^{+}$LSP cells are late commitment endothelial progenitor cells. The gene expression profile of CD $45^{-} / \mathrm{CD} 31^{+} / \mathrm{VEGFR} 2^{-}$LSP cells became almost identical to that of $\mathrm{CD}^{-} 5^{-} / \mathrm{CD} 31^{+} / \mathrm{VEGFR} 2^{+}$LSP cells following 2 days in culture, suggesting that $\mathrm{CD} 45 / \mathrm{CD} 31^{+} / \mathrm{VEGFR} 2^{+} \mathrm{LSP}$ cells may be derived from CD45/CD31+/VEGFR2- LSP cells (Fig. 6D).

The expression of $\alpha \mathrm{SMA}$ by freshly isolated CD $45^{-} / \mathrm{CD} 31^{+} /$VEGFR2- LSP cells suggested that they may serve a role as smooth muscle progenitors. To investigate this, the CD45/CD31 $/$ VEGFR2 ${ }^{-}$LSP cells were cultured in medium previously shown to promote smooth muscle differentiation (24). After 14 days in culture, many of the cells had developed the morphologic characteristics of smooth muscle cells, being large, flat, and stellate in appearance, and showing uniform immunostaining for $\alpha$ SMA and $\alpha$ SMT (Fig. 7A-F). To extend these findings, the gene expression profiles of freshly isolated and cultured CD $45 / \mathrm{CD} 31^{+} / \mathrm{VEGFR} 2-\mathrm{LSP}$ cells were compared. The mRNA expression of ABCG2 and CD13 was detected in the freshly isolated $\mathrm{CD} 45^{-} / \mathrm{CD} 31^{+} /$VEGFR2 LSP cells, however, the expression of these two genes was no longer detectable following 14 days in smooth muscle medium (Fig. 7G). By contrast, the CD $45 / \mathrm{CD} 31^{+} / \mathrm{VEGFR} 2$ LSP cells showed significantly upregulated expression levels of aSMA following 14 days in smooth muscle media, resulting in levels similar to those in the freshly isolated CD45 LMP cells (Fig. 7G). Following 14 days of culture in smooth muscle differentiation medium, the mature smooth muscle markers, $\alpha$ SMT and myosin heavy chain (35) were expressed by the 14-day-cultured CD $45^{-} / \mathrm{CD} 31^{+} / \mathrm{VEGFR} 2$ LSP cells and freshly isolated CD45 LMP cells, but not by the freshly isolated CD $45 / \mathrm{CD} 31^{+} / \mathrm{VEGFR2}$ LSP cells (Fig. 7G). By contrast, the CD $45 / \mathrm{CD} 31^{+} / \mathrm{VEGFR}^{+}$LSP cells did not express detectable mRNA levels of $\alpha$ SMA, $\alpha$ SMT or myosin heavy chain either before or after 14 days in smooth muscle differentiation medium (Fig. 7G). Therefore, although CD45/CD $31^{+} /$VEGFR2- LSP cells may be smooth muscle progenitor cells, the CD $45 \%$ CD $31^{+} /$VEGFR $2^{+}$LSP cells showed no such potential.

\section{Discussion}

There have been several reports of the existence of endogenous stem cell-like cell populations in the mouse lung $(14,25)$. In particular, the in vitro differentiation of $\mathrm{CD} 45^{-} / \mathrm{CD} 31^{-} \mathrm{LSP}$ cells was demonstrated by Summer et al (15). However, little is known about CD45/CD31 ${ }^{+}$LSP cells. The present study provides new data showing that $\mathrm{CD} 45^{\circ} / \mathrm{CD} 31^{+} \mathrm{LSP}$ cells can be divided into CD45/CD31/VEGFR2 ${ }^{-}$and CD $45 / \mathrm{CD} 31^{+} / \mathrm{VEGFR} 2^{+}$LSP cell subpopulations. To the best of our knowledge, this is the first detailed in vitro investigation of the ability of CD45/CD31 $1^{+}$LSP cells from the adult mouse lung to form cell colonies, differentiate into endothelial and smooth muscle cells and vascularize. The results suggest that CD $45 / \mathrm{CD} 31^{+} / \mathrm{VEGFR} 2^{+}$LSP cells differentiate into endothelial cells, whereas CD45/CD31 ${ }^{+} /$VEGFR2 ${ }^{-}$LSP cells can differentiate into endothelial and smooth muscle cells.

The expression of CD31 in CD $45 / \mathrm{CD} 31^{+} \mathrm{LSP}$ cells suggests that $\mathrm{CD} 45 / \mathrm{CD} 31^{+} /$VEGFR2 $2^{-}$and $\mathrm{CD} 45 / \mathrm{CD} 31^{+} /$VEGFR $2^{+}$LSP cells may be progenitors of lung endothelial cells. This was confirmed by their gene expression profiles. The CD $45 / C D 31^{+} /$VEGFR $2^{-}$and CD $45 \%$ CD $31^{+} / \mathrm{VEGFR}^{+}{ }^{+} \mathrm{LSP}$ cells expressed ABCG2 and CD133 at high levels. The endothelial cell marker vWF was undetectable in freshly isolated CD $45 / C D 31^{+} /$VEGFR2 LSPcells.TheCD $45 / C D 31^{+} /$VEGFR $2^{+}$ LSP cells expressed relatively low mRNA levels of vWF, and no vWF protein was detected. This phenotype is consistent with these SP cells being endothelial stem/progenitor cells $(27,36)$. Of note, the CD45/CD $31^{+}$LSP cells were capable of DiI-Ac-LDL uptake, suggesting that they were endothelial progenitors rather than hematopoietic progenitors. The expression levels of ABCG2 and CD133 were significantly lower in the $\mathrm{CD} 45 \% \mathrm{CD} 31^{+} / \mathrm{VEGFR} 2^{+} \mathrm{LSP}$ cells compared with those in the $\mathrm{CD} 45^{\circ} / \mathrm{CD} 31^{+} / \mathrm{VEGFR} 2$ LSP cells. In addition, the CD45/CD $31^{+} /$VEGFR2 LSP cells expressed $\alpha$ SMA, suggesting that these cells may serve as progenitors for endothelial and smooth muscle cells. This possibility is consistent with previous studies showing that vascular smooth muscle cells are derived from endothelial progenitor cells during vasculogenesis $(27,37)$. By contrast, the CD $45 / \mathrm{CD} 31^{+} / \mathrm{VEGFR} 2^{+}$LSP cells expressed detectable levels of vWF and VEGFR2, but no $\alpha \mathrm{SMA}$, indicating that these cells may be relative late commitment endothelial progenitor cells.

The results of the present study showed that $\mathrm{CD} 455^{-} / \mathrm{CD} 31^{+}$ LSP cells possessed a higher colony-forming potential than CD $45 \%$ CD $31^{+}$LMP cells. This finding is consistent with previous studies that reported SP cells isolated from different tissues have higher colony-forming capability than non-SP cells $(19,27,38)$. A previous study showed that a small number of cells isolated from the $\mathrm{CD} 31^{+}$population from the adult mouse lung were endothelial progenitor cells (39). This group of endothelial progenitor cells may be CD $45 / \mathrm{CD} 31^{+} \mathrm{LSP}$ cells. However, the data obtained in the present study do not rule out the possibility that other populations of $\mathrm{CD} 31^{+}$cells function as endothelial progenitor cells.

In a previous study, Irwin et al (16) showed that CD45/VEGFR2 ${ }^{+}$LSP cells of the mouse lung were able to differentiate into endothelial cells. However, whether these cells expressed CD31 was unclear. The present study found that it was possible to divide $\mathrm{CD} 45^{-} / \mathrm{CD} 31^{+} \mathrm{LSP}$ cells 
into $\mathrm{CD} 45^{\circ} / \mathrm{CD} 31^{+} / \mathrm{VEGFR} 2^{-}$and $\mathrm{CD} 45^{\circ} / \mathrm{CD} 31^{+} / \mathrm{VEGFR} 2^{+}$ sub-populations. Both the CD $45^{\circ} / \mathrm{CD} 31^{+} / \mathrm{VEGFR} 2^{-}$and CD $45^{-} / \mathrm{CD}^{2} 1^{+} / \mathrm{VEGFR} 2^{+}$LSP cells were capable of differentiation into mature endothelial cells, which formed vascular tube-like structures in vitro. However, only the CD $45 \%$ CD $31^{+} /$VEGFR2- LSP cells expressed $\alpha$ SMA and were capable of differentiation into mature smooth muscle cells in vitro (CD45/CD31 $/$ VEGFR2 ${ }^{+}$LSP cells did not). When the CD45/CD31 ${ }^{+} / \mathrm{VEGFR} 2^{-}$LSP cells were cultured under endothelial differentiation conditions for 2 days, the expression of $\alpha$ SMA was lost. They also started to express VEGFR2 and vWF. The gene expression profiles of those CD $45^{\circ} / \mathrm{CD}^{2} 1^{+} /$VEGFR2- LSP cells that had been cultured under endothelial differentiation conditions for 2 days became similar to that of CD $45 / \mathrm{CD} 31^{+} / \mathrm{VEGFR}^{+}{ }^{+} \mathrm{LSP}$ cells (Fig. 6C). Taken together, these findings indicate that the CD 45\%CD31 /VEGFR2- LSP cells were capable of differentiation into smooth muscle cells, endothelial cells and $\mathrm{CD} 45^{-} / \mathrm{CD} 31^{+} / \mathrm{VEGFR} 2^{+} \mathrm{LSP}$ cells in vitro. Therefore, CD $45 \% / C D 31^{+} / V_{E G F R}{ }^{+}$LSP cells may be late commitment endothelial progenitors that are capable of differentiating into endothelial cells, but not smooth muscle cells, in vitro. However, the association between CD $45^{-} / \mathrm{CD} 31^{+} / \mathrm{VEGFR} 2{ }^{-}$and CD $45 / \mathrm{CD}^{2} 1^{+} / \mathrm{VEGFR} 2^{+} \mathrm{LSP}$ cells requires further elucidation. Several studies have shown that SP cells from different tissues and organs have potential for repairing damaged parts within a tissue or organ (40-42). The role of CD45/CD $31^{+} \mathrm{LSP}$ cells in repairing injured lung tissue is to be the subject of a future investigation.

Our previous studies demonstrated that $\mathrm{CD} 31^{+} / \mathrm{SCA} 1^{+} \mathrm{CSP}$ cells served as endothelial progenitor cells in the adult mouse heart $(27,28)$. Of note, $\mathrm{SCA} 1^{+} / \mathrm{CD} 31^{+} \mathrm{CSP}$ cells share several features with CD $45^{-} / \mathrm{CD} 31^{+} \mathrm{LSP}$ cells (CD45/CD31+/VEGFR2and $\mathrm{CD} 45^{-} / \mathrm{CD} 31^{+} / \mathrm{VEGFR} 2^{-}$), including surface expression of SCA1, similarity in gene expression profiles, capacity for colony formation and potential for endothelial differentiation $(27,28)$. Our findings support the hypothesis that a novel population of progenitor cells may contribute to heart and lung tissues, including their blood vessels (26). Our previous study also demonstrated that vascular smooth muscle and airway smooth muscle share a common progenitor cell in the lung. Further investigation is required to determine whether $\mathrm{CD} 45^{\circ} / \mathrm{CD} 31^{+} / \mathrm{VEGFR} 2^{-}$LSP cells differentiate into airway smooth muscle cells. Previous studies have found that c-kit ${ }^{+}$cells in the adult mouse lung may serve as endothelial progenitor cells (11). However, the expression of c-kit was undetectable in $\mathrm{CD} 45^{-} / \mathrm{CD} 31^{+} \mathrm{LSP}$ cells. Therefore, the association between lung c-kit cells and CD $45^{-} / \mathrm{CD} 31^{+} \mathrm{LSP}$ cells also requires further investigation.

In conclusion, the present study isolated and characterized $\mathrm{CD} 45 \% \mathrm{CD} 31^{+} \mathrm{SP}$ cells from the adult mouse lung. They were found to consist of $\mathrm{CD} 45 \% \mathrm{CD} 31^{+} / \mathrm{VEGFR} 2$ and $\mathrm{CD} 45 \% \mathrm{CD} 31^{+} / \mathrm{VEGFR} 2^{+}$LSP cells. Based on their surface protein expression, their gene expression profile, and capacity to form colonies and differentiate into endothelial and smooth muscle cells in vitro, the results suggest that $\mathrm{CD} 45^{-} / \mathrm{CD} 31^{+} / \mathrm{VEGFR} 2^{-}$LSP cells may serve as a source of endothelial and smooth muscle progenitor cells in the adult mouse lung in vivo. The data also suggest that CD $45 \% \mathrm{CD}^{2} 1^{+} / \mathrm{VEGFR} 2^{+}$LSP cells may be derived from
CD $45 \% \mathrm{CD}^{\circ} 1^{+} / \mathrm{VEGFR}^{-}$LSP cells and that this differentiation may involve a lineage commitment to become endothelial progenitor cells. Understanding the function and identifying ways to promote the proliferation and differentiation of these populations of cells may offer potential for the development of novel therapeutic strategies to enhance vessel regeneration in lung injury and diseases.

\section{Acknowledgements}

Not applicable.

\section{Funding}

This study was supported by the National Natural Science Foundation of China (grant no. 81370619 to SXL).

\section{Availability of data and materials}

All data generated or analyzed during this study are included in this published article.

\section{Authors' contributions}

YX, PS and JYW performed experiments and wrote the manuscript; ZZL and RLG performed experiments; XZW performed analysis and interpretation of data; WDP analyzed data and edited the manuscript; SXL designed and organized the entire research, analyzed the data, and edited the manuscript. All the authors have read and approved the final, submitted version of manuscript.

\section{Ethics approval and consent to participate}

All animal experiments were conducted strictly according to ethical standards approved by the Animal Ethical Committee of Jinzhou Medical University (approval ID: LY2014D001).

\section{Patient consent for publication}

Not applicable.

\section{Competing interests}

The authors declare that they have no competing interests.

\section{References}

1. Schatz M, Kazzi AA, Brenner B, Camargo CA Jr, Corbridge T, Krishnan JA, Nowak R and Rachelefsky G: Joint task force report: Supplemental recommendations for the management and follow-up of asthma exacerbations. Introduction. J Allergy Clin Immunol 124 (2 Suppl): S1-S4, 2009.

2. Mosier JM, Hypes C, Joshi R, Whitmore S, Parthasarathy S and Cairns CB: Ventilator strategies and rescue therapies for management of acute respiratory failure in the emergency department. Ann Emerg Med 66: 529-541, 2015.

3. Yan Z, Kui Z and Ping Z: Reviews and prospectives of signaling pathway analysis in idiopathic pulmonary fibrosis. Autoimmun Rev 13: 1020-1025, 2014.

4. Cao Z, Lis R, Ginsberg M, Chavez D, Shido K, Rabbany SY, Fong GH, Sakmar TP, Rafii S and Ding BS: Targeting of the pulmonary capillary vascular niche promotes lung alveolar repair and ameliorates fibrosis. Nat Med 22: 154-162, 2016. 
5. Wong SP, Rowley JE, Redpath AN, Tilman JD, Fellous TG and Johnson JR: Pericytes, mesenchymal stem cells and their contributions to tissue repair. Pharmacol Ther 151: 107-120, 2015.

6. Marriott S, Baskir RS, Gaskill C, Menon S, Carrier EJ, Williams J, Talati M, Helm K, Alford CE, Kropski JA, et al: ABCG2pos lung mesenchymal stem cells are a novel pericyte subpopulation that contributes to fibrotic remodeling. Am J Physiol Cell Physiol 307: C684-C698, 2014.

7. Hung C, Linn G, Chow YH, Kobayashi A, Mittelsteadt K, Altemeier WA, Gharib SA, Schnapp LM and Duffield JS: Role of lung pericytes and resident fibroblasts in the pathogenesis of pulmonary fibrosis. Am J Respir Crit Care Med 188: 820-830, 2013.

8. Kramann R, Schneider RK, DiRocco DP, Machado F, Fleig S, Bondzie PA, Henderson JM, Ebert BL and Humphreys BD Perivascular $\mathrm{Gli}^{+}$progenitors are key contributors to injuryinduced organ fibrosis. Cell Stem Cell 16: 51-66, 2015.

9. Hong KU, Reynolds SD, Giangreco A, Hurley CM and Stripp BR Clara cell secretory protein-expressing cells of the airway neuroepithelial body microenvironment include a label-retaining subset and are critical for epithelial renewal after progenitor cell depletion. Am J Respir Cell Mol Biol 24: 671-681, 2001.

10. Barkauskas CE, Cronce MJ, Rackley CR, Bowie EJ, Keene DR, Stripp BR, Randell SH, Noble PW and Hogan BL: Type 2 alveolar cells are stem cells in adult lung. J Clin Invest 123: 3025-3036, 2013

11. Liu Q, Huang X, Zhang H, Tian X, He L, Yang R, Yan Y, Wang QD, Gillich A and Zhou B: c-kit(+) cells adopt vascular endothelial but not epithelial cell fates during lung maintenance and repair. Nat Med 21: 866-868, 2015.

12. Kajstura J, Rota M, Hall SR, Hosoda T, D'Amario D, Sanada F, Zheng H, Ogorek B, Rondon-Clavo C, Ferreira-Martins J, et al: Evidence for human lung stem cells. N Engl J Med 364: 1795-1806, 2011

13. Giangreco A, Shen H, Reynolds SD and Stripp BR: Molecular phenotype of airway side population cells. Am J Physiol Lung Cell Mol Physiol 286: L624-L630, 2004.

14. Liang SX, Summer R, Sun X and Fine A: Gene expression profiling and localization of Hoechst-effluxing CD45 and CD45 cells in the embryonic mouse lung. Physiol Genomics 23: 172-181, 2005.

15. Summer R, Fitzsimmons K, Dwyer D, Murphy J and Fine A Isolation of an adult mouse lung mesenchymal progenitor cell population. Am J Respir Cell Mol Biol 37: 152-159, 2007.

16. Irwin D, Helm K, Campbell N, Imamura M, Fagan K, Harral J, Carr M, Young KA, Klemm D, Gebb S, et al: Neonatal lung side population cells demonstrate endothelial potential and are altered in response to hyperoxia-induced lung simplification. Am J Physiol Lung Cell Mol Physiol 293: L941-L951, 2007.

17. Hierlihy AM, Seale P, Lobe CG, Rudnicki MA and Megeney LA The post-natal heart contains a myocardial stem cell population. FEBS Lett 530: 239-243, 2002.

18. Martin CM, Meeson AP, Robertson SM, Hawke TJ, Richardson JA, Bates S, Goetsch SC, Gallardo TD and Garry DJ: Persistent expression of the ATP-binding cassette transporter, Abcg2, identifies cardiac SP cells in the developing and adult heart. Dev Biol 265: 262-275, 2004.

19. Pfister O, Mouquet F, Jain M, Summer R, Helmes M, Fine A, Colucci WS and Liao R: CD31- but Not CD31 $1^{+}$cardiac side population cells exhibit functional cardiomyogenic differentiation. Circ Res 97: 52-61, 2005.

20. Zhou S, Schuetz JD, Bunting KD, Colapietro AM, Sampath J, Morris JJ, Lagutina I, Grosveld GC, Osawa M, Nakauchi H, et al: The ABC transporter Bcrp1/ABCG2 is expressed in a wide variety of stem cells and is a molecular determinant of the side-population phenotype. Nat Med 7: 1028-1034, 2001.

21. Goodell MA, Brose K, Paradis G, Conner AS and Mulligan RC: Isolation and functional properties of murine hematopoietic stem cells that are replicating in vivo. J Exp Med 183: 1797-1806, 1996.

22. Asakura A and Rudnicki MA: Side population cells from diverse adult tissues are capable of in vitro hematopoietic differentiation. Exp Hematol 30: 1339-1345, 2002.

23. Liang SX and Phillips WD: Migration of resident cardiac stem cells in myocardial infarction. Anat Rec 296: 184-191, 2013.

24. Summer R, Kotton DN, Liang S, Fitzsimmons K, Sun X and Fine A: Embryonic lung side population cells are hematopoietic and vascular precursors. Am J Respir Cell Mol Biol 33: 32-40, 2005.
25. Summer R, Kotton DN, Sun X, Ma B, Fitzsimmons K and Fine A Side population cells and Bcrpl expression in lung. Am J Physiol Lung Cell Mol Physiol 285: L97-L104, 2003.

26. Peng T, Tian Y, Boogerd CJ, Lu MM, Kadzik RS, Stewart KM, Evans SM and Morrisey EE: Coordination of heart and lung co-development by a multipotent cardiopulmonary progenitor. Nature 500: 589-592, 2013.

27. Liang SX, Khachigian LM, Ahmadi Z, Yang M, Liu S and Chong BH: In vitro and in vivo proliferation, differentiation and migration of cardiac endothelial progenitor cells $\left(\mathrm{SCA} 1^{+} / \mathrm{CD} 31^{+}\right.$ side-population cells). J Thromb Haemost 9: 1628-1637, 2011.

28. Wang XZ, Gao RL, Sun P, Liu S, Xu Y, Liang DZ, Yin LM, Phillips WD and Liang SX: Proliferation, differentiation and migration of SCA1 $/ \mathrm{CD} 31^{-}$cardiac side population cells in vitro and in vivo. Int J Cardiol 227: 378-386, 2017.

29. Liang SX, Tan TY, Gaudry L and Chong B: Differentiation and migration of $\mathrm{Sca}^{+} / \mathrm{CD} 31^{-}$cardiac side population cells in a murine myocardial ischemic model. Int J Cardiol 138: 40-49, 2010.

30. Sun P, Wu G, Gao RL, Liu S, Phillips WD and Liang SX: Rifampicin-dependent antibodies target glycoprotein IIb/IIIa and cause clearance of human platelets in NOD/SCID mice. Br J Haematol 172: 137-140, 2016.

31. Qiagen: QuantiTect Primer Assay Handbook. https://www. qiagen $. \mathrm{com} / \mathrm{sg} /$ resources/resourcedetail?id=882a8baa-29df-4182a2a5-17083f4dbe11\&lang=en. Accessed September 18, 2013.

32. Livak KJ and Schmittgen TD: Analysis of relative gene expression data using real-time quantitative PCR and the 2(-Delta Delta C(T)) method. Methods 25: 402-408, 2001.

33. Gehling UM, Ergun S, Schumacher U, Wagener C, Pantel K, Otte M, Schuch G, Schafhausen P, Mende T, Kilic N, et al: In vitro differentiation of endothelial cells from AC133-positive progenitor cells. Blood 95: 3106-3112, 2000.

34. Owens GK, Kumar MS and Wamhoff BR: Molecular regulation of vascular smooth muscle cell differentiation in development and disease. Physiol Rev 84: 767-801, 2004.

35. Low RB and White SL: Lung smooth muscle differentiation. Int J Biochem Cell Biol 30: 869-883, 1998.

36. Choi K, Kennedy M, Kazarov A, Papadimitriou JC and Keller G: A common precursor for hematopoietic and endothelial cells. Development 125: 725-732, 1998

37. Ema M, Faloon P,Zhang WJ, Hirashima M, Reid T, Stanford WL, Orkin S, Choi K and Rossant J: Combinatorial effects of Flk1 and Tall on vascular and hematopoietic development in the mouse. Genes Dev 17: 380-393, 2003.

38. Hirschmann-Jax C, Foster AE, Wulf GG, Nuchtern JG, Jax TW, Gobel U, Goodell MA and Brenner MK: A distinct 'side population' of cells with high drug efflux capacity in human tumor cells. Proc Natl Acad Sci USA 101: 14228-14233, 2004.

39. Schniedermann J, Rennecke M, Buttler K, Richter G, Stadtler AM, Norgall S, Badar M, Barleon B, May T, Wilting J, et al: Mouse lung contains endothelial progenitors with high capacity to form blood and lymphatic vessels. BMC Cell Biol 11: 1471-2121, 2010.

40. Ge G, Zhang H, Li R and Liu H: The function of SDF-1-CXCR4 axis in sp cells-mediated protective role for renal ischemia/reperfusion injury by SHH/GLI1-ABCG2 Pathway. Shock 47: 251-259, 2017.

41. He DN, Qin H, Liao L, Li N, Zhu WM, Yu BJ, Wu X, Zhao RC and Li JS: Small intestinal organoid-derived SP cells contribute to repair of irradiation-induced skin injury. Stem Cells Dev 14: 285-291, 2005.

42. Ooka H, Kanda S, Okazaki H, Suzuki H, Mishima K, Saito I, Yagi M, Tomoda $\mathrm{K}$ and Nishiyama T: Characterization of side population (SP) cells in murine cochlear nucleus. Acta Otolaryngol 132: 693-701, 2012.

This work is licensed under a Creative Commons Attribution-NonCommercial-NoDerivatives 4.0 International (CC BY-NC-ND 4.0) License. 